\title{
The Pharmaceutical Year that was, 2021
}

\author{
Anthony W. Fox ${ }^{1}$
}

Accepted: 12 September 2021 / Published online: 17 November 2021

(c) The Author(s), under exclusive licence to Springer Nature Switzerland AG 2021

Early in the review year (to meet the needs of the publishing process, it runs from September each year), there was a small inclusion criterion-related, pharmaceutical medicine component to the pandemic, namely some sensitivity and specificity data on the "AbC-19 Rapid" ${ }^{\circledR}$ test for detection of previous COVID-19 infection in key workers. Venous blood samples taken in the laboratory were used, and PCR-confirmed prior infection was the gold standard for comparison. The 95\% confidence interval for sensitivity (true positives) was $88.8-95.1 \%$, and the specificity (assessed using known negative samples) was $97.2-98 \%$. The test population had about $10 \%$ known positives. Thus, about "one in five key workers" testing positive were actually false positives [1]. In a wider population, which might comprise, in the UK, a relatively high prevalence of COVID-19 of, say, 300/100,000 $(0.3 \%)$, the false-positive test rate would therefore dwarf (by about ten-fold) the actual infected population. This has potential to create gross over-estimates for clinicians' treatment decisions (and politicians' miscalculations). Meanwhile, as is common, the diagnostic test had been given a CE mark based upon the manufacturer's self-assessment, and without scrutiny of any data or labelling by regulators.

Last year's editorial [2] noted that the French Government was prosecuting a large pharmaceutical company in connection with the well-known (for at least 40 years), lowincidence teratogenic effects of sodium valproate. Leaving aside the risk-benefit aspects (i.e. the disastrous effects of untreated epilepsy in pregnancy, and the hazards and relative effectiveness of alternative treatments), the defendant company stated it would rebut the charge vigorously, and demonstrate its regulatory compliance, sound standards of pharmacovigilance practice and overall transparency. This year, the litigation does not seem to have gone well for the French Government, which has now obtained an indictment, alleging negligence and manslaughter, against its own

Anthony W. Fox

phm@adis.com

1 Emeritus Editor, Pharmaceutical Medicine, London, UK national competent authority, L'Agence Nationale de Sécurité du Médicament et des Produits de Santé (ANSM) [3, 4]. This is starting to take on the characteristics of a classic gallic scandale, in an undisclosed, but doubtless complicated, political milieu.

Another piece of follow-up to last year's editorial [2] is that, on 11 January, 2021, the UK Professional Standards Authority suspended the accreditation of the Society of Homeopaths. The anti-vaccination position of the Society of Homeopaths finally reached the consciousness of the regulator via a consultation panel held just before Christmas. The implications are not huge: homeopaths cannot now describe themselves as being government accredited [5].

Some interesting commercial issues arose surrounding the pandemic in January. First, the State of Oklahoma attempted to return 1.2 million doses of hydroxychloroquine in order to recover US\$2 million that it spent on them last year. No other state had hedged their taxpayers' money on that unproven remedy (although Utah came close), and this is another example of what happens when personal opinion trumps 'following the science' [6]. A more unusual example was the basis for a dispute that arose between the Government of Sweden and Pfizer when the former stopped paying the latter for the COVID-19 vaccine. Apparently, the contract was priced per dose. Meanwhile, attempting to conserve vaccine supply, the European Medicines Agency made a variation to the product licence by declaring that the vial overfill was an additional dose. That meant that vials manufactured with five doses suddenly contained six doses, and, thus, could be invoiced accordingly [7].

Meanwhile, political tub thumping began when the European Commission threatened to ban vaccine exports to the UK from a Belgian manufacturing plant. Tempers cooled when those in Brussels realised that two plants in the UK were exporting vaccine into the European Union (EU) [8]. However, if the concept of tit-for-tat had dawned in the politicians' dim consciousness, then it was only temporary. As Spring rolled round, the EU was woefully behind countries such as the USA, Israel and the UK in rolling out its vaccine programme, and began blaming the manufacturers in 
general, and AstraZeneca, in particular. The French Government, in particular, embarked on a policy of demonising the AstraZeneca vaccine (which was being provided at cost), and several EU countries followed suit by suspending national licences. There were baseless accusations of lack of efficacy (e.g. in those over 65 years of age), and gross exaggerations of the risks of 'blood clots' (otherwise unspecified). Ludicrously, the EU even sued AstraZeneca for under-delivering vaccine supplies that its member states evidently did not want. The EU lost that case before its own European Court of Justice on 18 June [9].

In April, attention was drawn to the problems of industryfunded continuing medical education (CME) by a systematic review [10]. For a long time, it has been suspected that if their honoraria are paid by pharmaceutical companies, then physicians who deliver CME would make biased statements about particular products. This is not a new problem, although CME is mandatory in most US states. Even in the early 1990s, this author observed reputable companies providing CME sponsorship through an independent educational company, which acted essentially as a trustee that enforced compliance with standards of independence in forming programme content and materials. This new systematic review took into account publication bias against negative studies, and that the review included historical examples that might not be generalisable to the present, but nonetheless found a serious risk of bias among 21 of the 36 peerreviewed research papers on CME. The issue seems greatest for the USA, possibly because its medical system has fewer constraints on prescribing than those of developed countries with socialised healthcare systems, where national accreditation systems for CME and its providers are more common (www.accme.org).

In May, the UK Medicines and Healthcare products Regulatory Agency issued the final version of its guidance on the licensing of biosimilar products [11]. The biosimilar must undergo an extensive comparability exercise, showing its comparable quality to a reference product; this can include in vitro and/or animal model pharmacology. There must also be a confirmatory pharmacokinetic study, which may include pharmacodynamic biomarkers, if available. However :

"Although each biosimilar development needs to be evaluated on a case by case basis, it is considered that, in most cases, a comparative efficacy trial may not be necessary if sound scientific rationale supports this approach. Therefore, a well-argued justification for the absence of an efficacy trial should be appended to CTD Module 1 of the submitted application."

There are probably about 30 biologics that will lose exclusivity over the next 15 years in the UK, and developing biosimilar competitors should therefore become somewhat quicker and cheaper. For a socialised healthcare system, this is important because, with the limited experience so far, biosimilars are generally priced at about $50 \%$ of that for the reference product [12].

Plasminogen is the precursor of plasmin, and its deficiency is a rare autosomal recessive disorder with variable penetrance. As might be predicted, the phenotype includes the formation of fibrinous pseudomembranes, classically in the eye, but also in many other organs. These pseudomembranes have a 'woody' or ligneous appearance; patients may or may not also have recurrent thrombosis. On 4 June, a human plasminogen was approved by the US Food and Drug Administration (FDA) [Ryzplazim ${ }^{\circledR}$; Liminal Biosciences, Laval PQ Canada and Cambridge, UK] [13]. As might be expected, the review followed Orphan Drug Designation and Pediatric Orphan Drug Designation. Remarkably, the pivotal study had $n=15$ in a single arm [14]. As a rare regulatory event, the application benefitted from an FDA rare paediatric disease priority review voucher, which is awarded to encourage development of products with limited financial incentive. The duration of the FDA review has not been disclosed, although the Biological Licence Application was reported to have been resubmitted in September 2020 for a minimum review time of about 8 months.

In June, the Financial Times drew attention to an increase in both political and regulatory interest in anti-trust matters affecting the pharmaceutical industry in the USA. [15] Huge acquisitions (e.g. AbbVie acquiring Allergan for US\$63 billion, and Bristol-Myers Squibb buying Celgene for US $\$ 90$ billion) have been accompanied by extensive investigations by the US Federal Trade Commission and/or requirements to divest one or more products from the combined companies. In March, a 'working group', concentrating specifically on the pharmaceutical industry, was established by the governments of the UK, Canada and the EU. Meanwhile, there are several bills before the US Congress on this topic. Those are all at the 'macro' end of the anti-trust spectrum. It is as well to consider that there are also smaller, but kindred issues. These include the various schemes to pay for the delay of the introduction of a generic competitor, which, if legal, then certainly were not the intent of the legislation facilitating generic products in any country. Similarly, making small labelling or product changes (termed 'drug hopping') also has anti-competitive intent (see the judgement from Lord Sumption noticed in last year's review [2]). The pharmaceutical industry might do well to think not only globally about what is apparently underway at the governmental levels, but also to act locally about matters that are under their own control.

The most blatant example of anti-competitive behaviour this year seems to have taken place in the UK, and involved the humble generic hydrocortisone tablet. Actavis PLC and Auden Mckenzie PLC merged in 2015, and became 
Accord-UK PLC [16]. For almost 10 years, they had been paying AMCo/Advanz Pharma, and Waymade; the quid pro quo was for the latter not to market a competing product. Having cornered the market, the price of hydrocortisone 10 -mg and 20-mg tablet packs rose more than 100-fold, reaching a zenith of about $\mathrm{UK} £ 88$ for a product that had previously been sold for UK£0.70; National Health Service costs rose correspondingly from about UK£500,000 to UK£80 million, per annum. The total fines were UK£260 million distributed among the parties on both sides of this criminal deal, all of whom said they would appeal [17]. When will these charlatans ever learn?

Last, this year's bizarre therapy award goes to Australia, where imports of ivermectin have increased ten-fold. This is in spite of the fact that neither Australian cattle nor Australian humans have been especially wormy this winter. Rather, the Therapeutic Goods Administration (the Australian regulator) finds itself issuing the warning: "The TGA strongly discourages self-medication and self-dosing with Ivermectin for COVID-19 as it may be dangerous to your health. There is insufficient evidence to validate the use of Ivermectin in patients with COVID19." [18]. According to one journalist, that warning stimulated regulatory action on the part of the FDA, which took the form of a broadcasted 'tweet' about ivermectin; that 'tweet' had a helpful piece of biological education: "You are not a horse. You are not a cow. Seriously y'all. Stop it" (sic) [19]. To be fair, and remembering that the USA was last year's bizarre therapy winner, the FDA does have a potentially disinfectant-swallowing and disinfectant-injecting sub-population to worry about.

Happy New Year!

\section{Declarations}

Funding No funding was provided for the publication of this editorial.

Conflicts of interest Anthony W. Fox declares no conflicts of interest for this article.

Ethics approval Not applicable.

Consent to participate Not applicable.

Consent for publication Not applicable.

Availability of data and material Not applicable.

Code availability Not applicable.

Authors' contributions No other person was involved with this article.

\section{References}

1. Mulchandani R, Jones HE, Taylor-Phillips S, et al. Accuracy of UK Rapid Test Consortium (UK-RTC) "AbC-19 Rapid
Test" for detection of previous SARS-CoV-2 infection. BMJ. 2020;371:312.

2. Fox AW. The pharmaceutical year that was, 2020. Pharmaceut Med. 2020;34:365-8.

3. Dyer O. French drug regulator is indicted for manslaughter over sodium valproate birth defects. BMJ. 2020;371:m4446.

4. Jolly S. French medical regulator indicted for Sanofi epilepsy drug. Commercial risk 10 Nov 2020. https://www.commercial riskonline.com/french-medical-regulator-indicted-for-sanofiepilepsy-drug. Accessed 21 Nov 2020.

5. Professional Standards Authority. Society of homeopaths: review of conditions due October 2020. London: HMSO; 2021. p. 14.

6. Associated Press. Oklahoma seeking to return $\$ 2 \mathrm{M}$ worth of hydroxychloroquine. TRIBLive 27 Jan 2021. https://triblive. $\mathrm{com} /$ news/world/oklahoma-seeking-to-return-2m-worth-ofhydroxychloroquine/. Accessed 28 Jan 2021.

7. Anonymous. Sweden halts Pfizer payments over doses row. Daily Telegraph, 27 Jan 2021, p. 9.

8. Various statements made by politicians in Brussels and Paris, quoted widely by the Press, e.g., Crisp J. EU demands AstraZeneca diverts $75 \mathrm{~m}$ Covid jabs made in UK factories, at https:// www.msn.com/en-gb/money/companies/eu-demands-astrazeneca-diverts-75m-covid-jabs-made-in-uk-factories/ar-BB1d8 DPK?ocid=msedgdhp. Accessed 28 Jan 2021.

9. Anonymous. Covid vaccine: why did EU take AstraZeneca to court? BBC News, 18 Jun 2021. https://www.bbc.co.uk/news/ 56483766. Accessed 19 Jun 2021.

10. Mitchell AP, Trivedi NU, Gennarelli R, et al. Are financial payments from the pharmaceutical industry associated with physician prescribing? A systematic review. Ann Intern Med. 2021;174:353-61.

11. Medicines \& Healthcare products Regulatory Agency. Guidance on the licensing of biosimilar products (final version). London: 6 May 2021. https://www.gov.uk/government/publications/. Accessed 8 May 2021.

12. Anonymous. Drug appraisal. Assessing the efficacy and safety of Omnitrope. Br J Clin Pharm. 2010;2:298-301.

13. Inamdar S, Gallagher K. Liminal BioSciences announces FDA approval for its biologics license application for Ryplazim ${ }^{\circledR}$ (plasminogen, human-tvmh). Press release, Liminal Biosciences, Canada. June 4, 2021. https://liminalbiosciences.com/ resources/press-releases-2021/liminal-biosciences-announcesfda-approval-for-its-biologics-license-application-for-ryplazimplasminogen-human-tvmh. Accessed 10 Sep 2021.

14. Shapiro AD, Nakar C, Parker JM, et al. Plasminogen replacement therapy for the treatment of children and adults with congenital plasminogen deficiency. Blood. 2018;31:1301-10.

15. Baum A. Pharma investors must prepare for antitrust action. Financ Times Lond. 2021;4:14.

16. Competition and Markets Authority. Actavis/Auden Mackenzie merger inquiry. London: HMSO ME/6513/15; 2015.

17. Competition and Markets Authority. The CMA has imposed fines totalling over $£ 260$ million for competition law breaches in relation to the supply of hydrocortisone tablets. https://www. gov.uk/government/news/cma-finds-drug-companies-overc harged-nhs. Accessed 15 Jul 2021.

18. Therapeutic Goods Administration. Risks of importing ivermectin for treatment of COVID-19. 23 August 2021. www.tga.gov. $\mathrm{au} /$ media-release/risks-importing-ivermectin-treatment-covid19. Accessed 1 Sep 2021.

19. Taylor J. Australian imports of ivermectin increase tenfold, prompting warning from TGA. The Guardian online. 31 August 2021. www.msn.com/en-gb/news/world/australian-imports-ofivermectin-increase-tenfold-prompting-warning-from-tga/arAANUrh9?ocid=msedgntp. Accessed 1 Sep 2021. 